ante. As in the 1930s, the academic profession's concerted effort to strengthen the tenure system and defend academic freedom will be necessary to assure its survival.

doi: $10.1017 /$ heq.2018.21

\title{
The Paradox of Academic Freedom in the Chinese Context
}

\section{Qiang Zha and Wenqin Shen}

China aims to become an innovation-led nation by 2020, boosted by research excellence at its top universities, yet academic freedom has always been viewed as problematic in the country. ${ }^{1}$ Arguably, academic freedom should sit at the core of research excellence and innovation and be at the discretion of academia. China, however, features quite a different landscape. Recent academic integrity crises on university campuses and governmental intervention have once again brought the issue of academic freedom to the fore. To a large extent, the government oversees the academic integrity and outcomes of scholars and universities, unlike in the West, where this role is commonly fulfilled by the academic community. So what might be typically termed as "governmental interference" into academic affairs in the Western context appears to be the norm in the Chinese context. Such a scenario indicates a different view with respect to academic freedom in China. This article aims to shed light on this from the perspective of the Chinese knowledge

Qiang Zha is an Associate Professor and Director of the Graduate Program in Education at the Faculty of Education, York University, Canada. His research interests include Chinese and East Asian higher education, international academic relations, internationalization of higher education, among others, and touch upon academic freedom and university autonomy in the Chinese context. Wenqin Shen is an Associate Professor of Higher Education at the Graduate School of Education, Peking University, China. His research interests include the history of higher education, student mobility and internationalization, and doctoral education.

${ }^{1}$ Philip G. Altbach, "One-third of the globe: The future of higher education in China and India," Prospects 30, no. 1 (March 2009), 11-31; and Qiang Zha, "Academic Freedom and Public Intellectuals in China: A Century of Oscillations," International Higher Education 58 (Winter 2010), 17-18. 
tradition by using history to help understand why China and the West have such different academic traditions.

The limits to academic freedom in China are profoundly linked to the Chinese Confucian knowledge tradition. Confucius held a worldly view of knowledge, that is, knowledge starting with "the empirical cumulative understanding of masses of particulars, then linking these particulars to one's own experience, and subsequently to an underlying unity that tied everything together." 2 For Confucius, knowledge "remains indissolubly linked to the empirical world." ${ }^{3}$ He maintained that the "Tao [the Way] is not far from man. When a man pursues the Tao and remains away from man, his course cannot be considered the Tao." ${ }^{4}$ Noted historian Yu Ying-shih thus concludes that the "Chinese transcendental world of Tao and the actual world of everyday life were conceived from the very beginning to be related to each other in a way different from other ancient cultures." ${ }^{5}$ Indeed, the Confucian view of knowledge stands largely in contrast to the Western perspective (for example, the Platonic), whereby knowledge is often seen as being created through dialectical reasoning in the form of questions, answers, and exchanging arguments, and that perception requires a rigorous process of deductive logic. ${ }^{6}$

This scrutiny into the Confucian knowledge tradition sheds light on the source of a fundamental paradox. On one hand, Chinese scholars long for discretion over their academic affairs, which would benefit Chinese universities' drive for world-class standing. On the other hand, aspects of the Confucian values could constrain Chinese scholars in their academic pursuits. In the Confucian tradition, knowledge is less a matter of understanding the world than of changing it, and scholars are expected to "cultivate the self, manage the family, govern the country, and bring peace to the world" (a famous quote originated in the Great Learning-a classic Confucian text-that defined the archetypal Confucian scholar). More

${ }^{2}$ Ruth Hayhoe, "Philosophy and Comparative Education: What Can We Learn from East Asia?" in Comparative and International Education: Issues for Teachers, ed. Karen Mundy, Kathy Bickmore, Ruth Hayhoe, Meggan Madden, and Kathy Madjidi (Toronto: Canadian Scholars Press, 2008), 26.

${ }^{3}$ Benjamin I. Schwartz, The World of Thought in Ancient China (Cambridge, MA: Harvard University Press, 1985), 95.

${ }^{4} \mathrm{Yu}$-Ying-shih, "Address of Yu-Ying-shih on the Occasion of Receiving the John W. Kluge Prize at the Library of Congress," Dec. 5, 2006, Library of Congress, https://www.loc.gov/item/prn-06-a07/remarks-of-yu-ying-shih-2006kluge-prize/2006-12-05/.

5 "Address of Yu-Ying-shih."

${ }^{6}$ Qiang Zha, "Is There an Emerging Chinese Model of the University?," in Portraits of 21st Century Chinese Universities: In the Move to Mass Higher Education, ed. Ruth Hayhoe, Jun Li, Jing Lin, and Qiang Zha (Hong Kong: Comparative Education Research Centre, 2011), 451-71. 
explicitly, scholars ought to seek unity of knowledge and action through their roles as "action intellectuals," often within the political regime- for example, taking a government office and testing their knowledge in the tasks required for managing that office - rather than seeking knowledge for its own sake and functioning as an independent social critic or as a public intellectual, which is often seen in many Western societies. As Neo-Confucian Tu Weiming insightfully observes:

Confucian followers were primarily action intellectuals, deeply immersed in "managing the world" (jingshi) of economics, politics, and society. Their strategy was to transform the world ... through culture, specifically through moral education. ... Confucian scholar-officials were perceived of as the conscience of the people, for they served the long-term well-being of the entire country. ${ }^{7}$

As such, academic freedom that is a "totem" for the vast majority of American scholars ${ }^{8}$ may not necessarily be highly expected for some Chinese scholars, and they may sacrifice their faith in academic freedom to serve the interests of the people and the government.

Indeed, the Confucian knowledge tradition is closely linked with social and political life, with an emphasis on the Confucian intellectuals' dedicated and direct responsibility for ensuring social order and benevolent governance. This tradition strongly encouraged moral responsibility toward others and collective well-being. Confucius once said that "a humane person, in wishing to establish self, establishes others; in wishing to enlighten self, enlightens others." This notion may be responsible for a tendency toward pan-moralism in the Confucian tradition, in which separating knowledge and action, and failing to connect one's pursuit of knowledge to the national interest, would be seen as a lack of ethics and could deprive one of the privileged status as an intellectual. Such values resonate in the present day, as evidenced in the recent remark made by China's Leader when meeting with the Advisory Board of Tsinghua University School of Economics and Management, that Chinese universities, rather than bringing forth bystanders or opponents, are to produce builders and successors of socialism with Chinese characteristics. ${ }^{10}$ Such

${ }^{7}$ Tu Weiming, "Intellectuals in a World Made of Knowledge," Canadian Journal of Sociology 30, no. 2 (Spring 2005), 200.

${ }^{8}$ Burton R. Clark, The Academic Life: Small Worlds, Different Worlds (Princeton, NJ: Carnegie Foundation for the Advancement of Teaching, 1987), 135.

${ }^{9}$ Confucius, Analects, trans. John B. Khu, Vicente B. K. Khu, William B. S. Khu, and Jose B. K. Khu (Beijing: World Affairs Press, 1996), Chapter 6 Text 30 (6:30), 94.

${ }^{10}$ Xinhua (News Agency), "Opening up of China means win-win cooperation for world: President Xi." October 31, 2017, http://en.people.cn/n3/2017/1031/c900009286630.html. 
a mentality could render Chinese scholars, especially those in the humanities and social sciences, particularly vulnerable in the face of political power and social changes and in a danger of cynicism, that is, a tendency to go along with the powerful and predominant. For example, Chinese universities and scholars are enthusiastic about instituting public policy think tanks on campus and having government officials and leaders recognize their work. Once such a reciprocal knowledge-power nexus is firmly in place, even scientists may become keen to take up governmental positions, and many of them may socialize with powerful bureaucrats and their favorite experts in order to obtain major research grants. ${ }^{11}$ Arguably, such a knowledge tradition is likely to stymie innovation.

The above narrative might provide a gloomy scene with respect to academic freedom in China. However, we argue that freedom to research and publish is not forever doomed there. Tensions behind the scenes at top Chinese universities could drive important changes and possibilities. Also, from time to time it is not surprising to see a kind of swinging back and forth with respect to academic freedom and university autonomy. ${ }^{12}$ Specifically, two sets of tensions relate to the discourse in this article: those between orthodox and NeoConfucian norms and those between traditional Chinese elements and Western ones. They are elaborated below.

First, William Theodore de Bary points to a liberal tradition in Confucianism that aligns with Neo-Confucianism in stressing "the idea of self-renewal as the basis for a larger human renewal" and that places social renewal in individual perfectibility. ${ }^{13}$ This contrasts with orthodox Confucianism in deviating from collectivism and paying attention to individualism. Arguably, Confucian liberalism is mostly embodied with shuyuan (private academies) flourishing in the Tang and Song dynasties, which are vastly different from the imperial educational system based on orthodox notions of Confucianism. Essentially, shuyuan encourages an independent ethos that tolerates different schools of thought and maintains that "to this attainment

${ }^{11}$ Yigong Shi and Yi Rao, "China's Research Culture," Science 329, no. 5996 (Sept. 3, 2010), 1128.

${ }^{12}$ Qiang Zha, "Academic Freedom and Public Intellectuals in China: A Century of Oscillations" International Higher Education, no. 58 (2010), 17-18; and Qiang Zha and Fengqiao Yan, "Oscillations and Persistence in Chinese Higher Education Policy: A Path Dependence Analysis," in Making Policy in Turbulent Times: Challenges and Prospects for Higher Education, ed. Paul Axelrod, Roopa Desai Trilokekar, Theresa Shanahan, and Richard Wellen (Montreal: McGill-Queen's University Press, 2013), 317-38.

${ }^{13}$ William Theodore de Bary, The Liberal Tradition in China (Hong Kong: Chinese University Press, 1983), 12. 
there are requisite the extensive study of what is good, accurate inquiry about it, careful reflection on it, the clear discrimination of it, and the earnest practice of it." 14 This emphasis on learning for the sake of one's self clearly signifies the individualistic orientation in Confucian liberalism. ${ }^{15}$ As students and scholars direct their own learning, they cannot help but become "intrinsically free" to pursue the limits of knowledge. ${ }^{16}$ As such, there is a kind of continuity between progressive aspects of Confucian liberalism and academic freedom in the modern sense.

A second set of tensions, between traditional Chinese elements of academia and Western notions, arose during the late Qing dynasty in the late nineteenth and early twentieth centuries. At that time, Western conceptions of academic freedom began to have an impact in China. In this process, some Chinese academics came to accept the concept of academic freedom, together with such associated ideas as freedom of expression and publication. Arguably, academics who returned from the West played a pivotal role in this process. Here, Cai Yuanpei is an example, given his status and influence in contemporary Chinese higher education. Between 1907 and 1911, Cai studied philosophy, aesthetics, anthropology, and experimental psychology at the University of Leipzig in Germany. During his four-year sojourn, he was impressed by the freedom German universities enjoyed. ${ }^{17}$ He returned to China in 1912 and served as the first minister of education in the new Republic of China. Between 1916 and 1926, he served as the chancellor of Peking University. During this period, he was enthusiastic about synthesizing important ideas and experiences from China and the West to reform and advance Chinese universities. In particular, he was devoted to independent thinking and tolerating different intellectuals, claiming, "We must follow the general rule of freedom of thought and freedom of expression,

${ }^{14}$ The Doctrine of the Mean, XX.19, trans. James Legge, http://nothingistic.org/ library/confucius/mean/mean04.html.

${ }^{15}$ Wing On Lee, "The Cultural Context for Chinese Learners: Conceptions of Learning in the Confucian Tradition," in The Chinese Learner: Cultural, Psychological and Contextual Influences, ed. David A. Watkins and John B. Biggs (Hong Kong: Comparative Education Research Centre, 1996); and Thomas H. C. Lee, Education in Traditional China: A History (Leiden, Neth.: Brill, 2000).

${ }^{16}$ Weiming Tu, "Beyond the Enlightenment Mentality," in Confucianism and Ecology: The Interrelation of Heaven, Earth, and Humans, ed. Mary Evelyn Tucker and John Berthrong (Cambridge, MA: Harvard University Press, 1998), 14.

${ }^{17}$ Hongiie Chen, "Die chinesische Rezeption der Humboldt'schen Universitätsidee. Am Beispiel der Universität Peking zu Anfang des 20. Jahrhunderts," in Humboldt International: Der Export des Deutschen Universitätsmodells im 19. und 20 (Jahrhundert: Schwabe \& Company, 2001). 
and not allow any one branch of philosophy or any one tenet of religion to confine our minds," 18 and "With respect to the teaching staff, scholarship will be the main criterion for their appointment. Their work of teaching will also be guided by the principle of freedom of thought." ${ }^{19}$ His adherence to the principle of academic freedom enabled Peking University to attract and recruit many renowned scholars representing different schools of thought, which allowed the university to quickly emerge as one of China's top universities. Today, hundreds of thousands of scholars returning from the West participate in China's drive to foster world-class universities, and they may be the fertile soil that creates academic freedom in China, although a winding process and some uneven development resulting from differences in the institutional legacy and ethos are inevitable.

China now strives to have first-rate universities, which is not possible without academic freedom. ${ }^{20}$ The pressing need to deal with the paradoxes discussed, due to the constraints on scholars from the Confucian knowledge tradition, is a huge challenge for both the Chinese government and academia. On one hand, the enduring Confucian tradition limits Chinese scholars' ability to research and publish materials unrelated to strengthening the state; on the other, some aspects of Neo-Confucianism and the inclusion of Western ideas about academic freedom have enabled more and more Chinese scholars to seek intellectual freedom. These tensions, particular to China, may seem as if they would complicate progress and the flourishing of academic freedom in China. However, academic freedom in China does not have to exactly mirror Western notions. Academic freedom is not absolute, and like freedom itself, it is often conditioned by particular historical and social contexts. ${ }^{21}$ In this sense, a kind of Chinese-flavored academic freedom could emerge to allow Chinese institutions of higher education to become the world-class institutions to which they aspire.

doi: $10.1017 /$ heq.2018.22

${ }^{18}$ Gao Pingshu, ed., Cai Yuanpei Quanji (The Complete Works of Cai Yuanpei), vol. 2 (Beijing: Zhonghua Press, 1984), 134.

${ }^{19}$ Gao, Cai Yuanpei Quanji, vol. 3, 271.

${ }^{20}$ Richard C. Levin, "Top of the Class: The Rise of Asia's Universities," Foreign Affairs 89, no. 3 (May-June 2010), 63-75.

${ }^{21}$ Paul Axelrod, "Academic Freedom: Can History Be Our Guide?," Jan. 24, 2018, University Affairs, https://www.universityaffairs.ca/features/feature-article/ academic-freedom-can-history-guide/. 